Dukhnevych A., Karpinska N. Mediation Procedure (Reconciliation) in the Criminal Proceedings Against a Minor. The article highlights the issue of introducing the institute of mediation in Ukraine. The author reviews the main provisions of the Singapore Convention on Mediation, which enters into force on 12 September 2020, the draft Law on Mediation (№ 3504 of 19, May 2020) submitted by the Cabinet of Ministers of Ukraine, and the alternative draft Law on Mediation (№ 3504-1 of 4, June 2020), submitted by the People's Deputies of Ukraine. The author interprets the legal status of a mediator as a specific and obligatory participant in the mediation process and substantiates the necessity and prospects of pre-trial settlement of disputes through mediation. The article highlights the concepts, principles, and forms of restorative justice and distinguishes restorative justice from official criminal proceedings. The author argues that mediation, as a form of the restorative justice, is an effective way of reconciliation of the victim with a juvenile offender. The procedure of mediation uses provisions of the criminal procedure law concerning the criminal proceedings based on agreements. In view of this, the authors suggest their own ideas as to the conditions for the improvement of mediation procedure in criminal proceedings and its implementation in Ukraine. The process of reforming criminal justice for juveniles should make taking into account international recommendations and standards and move towards the implementation of restorative justice. The main reasons that hinder the spread of restorative justice in Ukraine are, first of all, the specifics of national justice, focused mainly on punishment, insufficient regulation in criminal procedure law of the procedure for concluding agreements with juvenile suspects, accused, low awareness of citizens about the opportunity of conducting restorative justice procedures in juvenile cases and ignorance about them among the participants in the criminal proceedings.

Key words: mediation, conflict (dispute), pre-trial settlement of dispute, reconciliation, juvenile, restorative justice.

УДК 342.98

DOI https://doi.org/10.32782/2409-4544/2020-1/17

Г. Андрусяк

\title{
Суть суспільно небезпечного посягання в контексті підстави необхідної оборони
}

У статті обгрунтована правильність визначення підстави необхідної оборони як суспільно небезпечного посягання. Визначено семантику поняття «підстава», адже цей термін є багатозначним. . Підставою необхідної оборони $є$ вчинення суспільно небезпечного посягання. Слід схвалити використання законодавцем саме такого терміна, а не «напад» чи «злочинне посягання». Не можна погодитись і з використанням поняття «напад» для характеристики підстави необхідної оборони. Напад зажди містить елемент насильства. Проте суспільно небезпечне посягання може здійснюватися 3 використанням безпорадного стану потерпілої особи. Згідно з буквальним тлумаченням закону підставою необхідної оборони є посягання, що становить суспільну небезпеку і не обов'язково $\epsilon$ злочинним. Злочинність діяння означає наявність всіх ознак складу злочину - вчинення суб' єктом злочину передбаченого кримінальним законом суспільно небезпечного діяння. Згідно з висновками автора при необхідній обороні посягання повинно бути спрямовано на державні, громадські інтереси, а також політичні, трудові та майнові права громадян, особу, ії честь і гідність, щоб посягання и можна було кваліфікувати як суспільно небезпечне. Підставою необхідної оборони може бути і таке суспільно небезпечне посягання, яке не утворює нападу. Оскільки в законі йдеться про запобігання або припинення спроби особи вчинити дію, яке створює суспільну небезпеку, очевидно, мається на увазі певна активність особистості. У законі не вказано, що посягання повинно бути пов'язане 3 насильством, воно повинно бути суспільно небезпечним. Проаналізована наукова дискусія про можливість необхідної оборони проти посягання у формі бездіяльності. Серед всіх обставин, що виключають злочинність діяння, тільки необхідна оборона - це реакція на суспільно небезпечне посягання, яке можливо і в активній, і в пасивній формі. На думку автора, немає підстави для права на необхідну оборону при суспільно небезпечній бездіяльності.

Ключові слова: необхідна оборона, напад, підстава необхідної оборони, суспільно небезпечне посягання, бездіяльність.

(C) Андрусяк Г., 2020 
Постановка наукової проблеми та їі значення. Необхідна оборона, будучи дією правомірною, водночас полягає у заподіянні шкоди іншій особі, що в окремих випадках кваліфікується як злочин. Тому, особливого значення набуває поняття та характеристика підстави необхідної оборони.

Аналіз останніх досліджень і публікацій. У нашому дослідженні було проаналізовано наукові праці таких вітчизняних та закордонних вчених, як М. І. Бажанов, С. В. Бородін, О. О. Кваша, $\begin{array}{llll}\text { O. М. Костенко, } & \text { О. Ф. Кістяківський, } & \text { В. Б. Малінін, } & \text { В. В. Меркур'єв, }\end{array}$ В. О. Навроцький, Т. Г. Шавгулідзе.

Метою статті є встановлення поняття «підстава», зміст та значення суспільно небезпечного посягання в системі досліджень необхідної оборони.

Виклад основного матеріалу дослідження та обгрунтування отриманих результатів дослідження. У кримінальному праві України підставою необхідної оборони є суспільно небезпечне посягання. Сутність цього поняття не міститься в КК України, а також спеціально не роз'яснюється у Постанові Пленуму Верховного Суду України від 16.04.2002 «Про судову практику в справах про необхідну оборону». Український вчений XIX століття О. Ф. Кістяківський наполягав на тому, що підстава права необхідної оборони лежить у природному, невід'ємно належному людині загальному праві самозахисту і самооборони від усякої загрозливої його законному добробутові небезпеки, звідки б вона не виходила. Серед підстав, які створюють юридичний стан необхідної оборони, вчений відзначав «коли жінка піддається насильницькому посяганню на цнотливість і честь» [1, с. 413].

Загалом під суспільно небезпечним посяганням слід розуміти активні дії особи, спрямовані на спричинення шкоди правам чи інтересам особи, суспільним чи державним інтересам, що охороняються кримінальним законом України.

Посягання має бути об'єктивно суспільно небезпечним, і при цьому не обов'язково злочинним. Однак даного висновку недостатньо для відповіді на питання, що ж розуміється під суспільною небезпекою як основною властивістю посягання. У кримінально-правовій науці існує позиція, що суспільна небезпека полягає в тому, що посягання заподіює або може заподіяти істотну шкоду правоохоронюваним інтересам [2, с. 6]. Подібної точки зору дотримується М. Й. Коржанський, зазначаючи, що напад повинен загрожувати тяжкими наслідками у сфері важливих суспільних цінностей - життя, здоров'я, власності, державного управління та ін. [3, с. 219]. Суть представленої позиції полягає в тому, що право на необхідну оборону обмежується лише стосовно тих ситуацій, коли суспільна небезпека посягання виражається в «істотній» шкоді або «тяжких» наслідках. Інші вчені наполягають, що суспільно небезпечним посяганням є діяння, що заподіює шкоду особистості, охоронюваним законом суспільним і державним інтересам, або створює загрозу заподіяння шкоди [4, c. 27]. Більш конкретно суть даної точки зору на суспільну небезпеку посягання виражається в такий спосіб: суспільно небезпечним варто вважати посягання, ознаки якого зазначені в будь-якій статті Особливої частини кримінального закону [5, с. 12]. Ми згодні з думкою, що при необхідній обороні посягання, щоб кваліфікуватися, як суспільно небезпечне повинно бути спрямоване на «державні, суспільні інтереси, а також політичні, трудові і майнові права громадян, особистості, іiі честі і достоїнства» [6, с. 219]. Остання точка зору переважно обумовлена тим, що впродовж тривалого часу судова практика при розгляді справ даної категорії керувалася роз'ясненням постанови Пленуму Верховного Суду СРСР від 16.08.1984 № 16 «Про застосування судами законодавства, що забезпечує право на необхідну оборону від суспільно небезпечних посягань». Згідно 3 цим роз'ясненням під суспільно небезпечним посяганням, від якого допускається захист, розумілося діяння, передбачене Особливою частиною кримінального закону, незалежно від того, чи притягнута особа, яка його вчинила, до кримінальної відповідальності, чи звільнена від неї у зв'язку 3 неосудністю, недосягненням віку притягнення до кримінальної відповідальності або з інших підстав. Зазначена постанова була вдалішою в цій частині, ніж пізніші постанови Пленуму Верховного Суду України від 28.06.1991 № 4 «Про практику застосування судами законодавства, що забезпечує право на необхідну оборону від суспільно небезпечних посягань», та від 26.04.2002 № 1 «Про судову практику у справах про необхідну оборону». Названі постанови не роз'яснюють питання про сутність суспільної небезпеки посягання. Зокрема, у пункті 3 постанови від 16.08.1984 йдеться про сильне душевне хвилювання, яке може виникнути в особи у стані необхідної оборони, у зв'язку з чим згадується «суспільно небезпечне посягання на законні права, інтереси, життя і здоров'я людини, суспільні інтереси чи інтереси держави» [7, с. 287]. 
Незважаючи на невизначеність даного питання ні в законі, а ні в роз'ясненнях вищої судової інстанції України, у теорії кримінального права на сучасному етапі домінує позиція, що при необхідній обороні коло правоохоронюваних інтересів, на які може посягати особа, є практично необмеженим [8, с. 251]. I при цьому суспільно небезпечним посяганням є не лише злочинне посягання, а й будь-яке інше суспільно небезпечне посягання (посягання неосудних осіб або осіб, які не досягли віку криміальної відповідальності).

Слід визначити семантику поняття «підстава», адже цей термін $є$ багатозначним. За словником В. Даля, до якого традиційно звертаються дослідники за тлумаченням слів, підстава визначається як: усе, на чому будь-що засновано, поставлено чи укріплено; що слугує підошвою, підніжжям, фундаментом; опора, початок, причина [9, с. 700-701]. Сучасна українська мова визначає підставу як «те головне, на чому базується, грунтується, засновується що-небудь» [10, с. 665]. У юридичній науці поняття підстави також визначається з урахуванням вище наведених положень, тому наявність підстави необхідної оборони ми вважаємо головною умовою необхідної оборони.

Підставою необхідної оборони є вчинення суспільно небезпечного посягання. Слід схвалити використання законодавцем саме такого терміна, а не «напад» чи «злочинне посягання». I тим більше не можна погодитися 3 тезою «говорячи про злочин як про підставу необхідної оборони...» [11, c. 140]. Розуміння злочинного посягання як підстави необхідної оборони призводить до того, що правомірна оборона від незлочинних, але все ж суспільно небезпечних дій (наприклад, скоєних малолітньою або психічно хворою особою) визнається неприпустимою і підпадає під ознаки крайньої необхідності [12, с. 112]. Згідно з буквальним тлумаченням закону підставою необхідної оборони $\epsilon$ посягання, що становить суспільну небезпеку і не обов'язково $\epsilon$ злочинним. Злочинність діяння означає наявність всіх ознак складу злочину - вчинення суб'єктом злочину передбаченого кримінальним законом суспільно небезпечного діяння. Як відомо, статеві злочини вчиняються i малолітніми особами, однак хіба це позбавляє потерпілу права на необхідну оборону? Очевидно, що посягання на статеву свободу чи статеву недоторканість, скоєне психічно нездоровою людиною, в принципі, не є менш суспільно небезпечним, ніж посягання особи осудної.

Суспільна небезпека діяння не рівнозначна його злочинності, тому що злочин характеризується визначеною сукупністю ознак, і суспільна небезпека - лише одна з передбачених у законі ознак. Не можна погодитись і з використанням поняття «напад» для характеристики підстави необхідної оборони. Напад зажди містить елемент насильства. Нерідко суспільно небезпечне посягання виражається в нападі особи чи групи осіб (розбійний напад, напад з метою вбивства людини тощо). I хоча згвалтування за КК України - це статеві зносини із застосуванням фізичного насильства, згвалтування може здійснюватися з використанням безпорадного стану потерпілої особи. Тому підставою необхідної оборони може бути і таке суспільно небезпечне посягання, яке не утворює нападу. Так, О. О. Баранова слушно зауважує, що до посягань, не пов’язаних з нападом, для захисту від яких правомірна необхідна оборона, можна віднести згвалтування, вимагання, порушення недоторканності житла, хуліганство, замах на вбивство шляхом отруєння та інші суспільно небезпечні діяння [13, с. 36].

Такий висновок, однак, залишає невирішеною ще одну проблему: чи може посягання здійснюватися шляхом бездіяльності? Превалює позиція, що суспільно небезпечне посягання як підстава для оборони - це дії особи, спрямовані на спричинення шкоди правам чи інтересам особи, суспільним чи державним інтересам, що охороняються кримінальним законом України, незалежно від наявності в цих діях всіх суб'єктивних ознак злочину $[14$, с. 66]. На нашу думку, більш обгрунтованими $є$ позиції тих вчених, які заперечують можливість права на необхідну оборону при суспільно небезпечній бездіяльності [15, с. 27]. Згідно з частиною першою статті 36 КК України необхідною обороною визнаються «дії, вчинені з метою захисту... від суспільно небезпечного посягання шляхом заподіяння тому, хто посягає, шкоди...». У словнику С. І. Ожегова слово «посягнути» трактується як спроба зробити що-небудь [16, с. 493].

Висновки. При необхідній обороні посягання, щоб кваліфікуватися, як суспільно небезпечне повинно бути спрямоване на «державні, суспільні інтереси, а також політичні, трудові і майнові права громадян, особистості, іiї честі і достоїнства». Підставою необхідної оборони може бути і таке суспільно небезпечне посягання, яке не утворює нападу. Оскільки в законі йдеться про запобігання або припинення спроби особи вчинити дію, що становить суспільну небезпеку, очевидно, мається на увазі певна активність особи. У законі не вказано, що посягання має бути поєднане 3 насильством, воно має бути суспільно небезпечним. Серед усіх обставин, що виключають злочинність діяння, лише необхідна оборона - це реакція на суспільно небезпечне посягання, яке можливе і в активній формі, i в пасивній. 


\section{Джерела та література}

1. Кістяківський О. Ф. Елементарний підручник загального кримінального права 3 детальним викладом засад російського кримінального законодавства. Загальна частина / О. Ф. Кістяківський- [3є вид. передрук. без змін з другого]. - [Репр. вид.]. - К.: Вид. ПАЛИВОДА А. В., 2009. - 906 с.

2. Берестовой Н. П. Право граждан на необходимую оборону (в помощь лектору) / Н. П. Берестовой. Ленинград: Знание, 1986. - 16 с.

3. Коржанський М. Й. Уголовне право України. Частина загальна : [курс лекцій] / М. Й. Коржанський. - К.: Наукова думка та Українська видавнича група, 1996. - 336 с.

4. Ткаченко В. Необходимая оборона / В. Ткаченко // Законность. - 1997. - № 3. - С. 26-29.

5. Дурманов Н. Д. Советское уголовное право: Обстоятельства, исключающие общественную опасность и противоправность деяния. Часть общая / Н. Д. Дурманов; [ред.: М. А. Гельфер, П. П. Гришаев, Б. В. Здравомыслов (отв. ред.)]. - М.: ВЮЗИ, 1961. - Вып. 9. - 45 с.

\begin{tabular}{l} 
6. Уголовное право Украинской ССР на современном этапе: Часть общая / [Ф.Г. Бурчак, \\
\hline
\end{tabular} И. П. Лановенко, А. М. Яковлев и др.]. - К.: Наукова думка, 1985. - 447 с.

7. Постанови Пленуму Верховного Суду України 1972-2002: офіційне видання / [за заг. ред. В. Т. Маляренка]. - К.: А.С.К., 2003. - 287 с.

8. Кримінальне право України: Загальна частина: підручник для студ. юрид. спец. вищ. закладів освіти / [М. І. Бажанов, Ю. В. Баулін, В. І. Борисов та ін.]; за ред. М. І. Бажанова, В. В. Сташиса, В. Я. Тація. - Київ-Харків: Юрінком Інтер-Право, 2002. - 416 с.

9. Даль В. Толковый словарь живаго великорускаго языка / В. Даль. - М.: Изд. Книгопродавцатипографа М. О. Вольфа, 1881. - Т. 2. - 779 с.

10. Новий тлумачний словник української мови: в 3 т. / [уклад.: В. Яременко, О. Сліпушко]. - [2-е вид., виправ.]. - Т. 2: К - П. - К.: АКОНІТ, 2008. -928 с.

11. Налбандян М. С. Некоторые вопросы института необходимой обороны / М. С. Налбандян // Вектор науки ТГУ. - 2010. - № 3. - С. 139-143.

12. Сахаров А.Б. Обстоятельства, исключающие уголовную ответственность / А.Б. Сахаров // Советское государство и право. - 1987. - № 11. - С. 111-119.

13. Баранова Е. А. Необходимая оборона [монография] / Е. А. Баранова. - М.: Юрлитинформ, 2007. $152 \mathrm{c}$.

14. Слуцкий И. И. Обстоятельства, исключающие уголовную ответственность / И. И. Слуцкий. Ленинград: ЛГУ, 1956. - 118 с.

15. Баулин Ю. В. Обстоятельства, исключающие преступность деяния / Ю. В. Баулин. - Харьков: Основа, 1991. - 360 с.

16. Ожегов С. И. Словарь русского языка / С. И. Ожегов. - М.: Наука, 1984. - 797 с.

Андрусяк Г. Суть общественно опасного посягательства в контексте основания необходимой обороны. В статье обоснована правильность определения основания необходимой обороны как общественно опасного посягательства. Определена семантика понятия «основание», ведь этот термин является многозначным. Основанием необходимой обороны является совершение общественно опасного посягательства. Следует одобрить использование законодателем именно такого термина, а не «нападение» или «преступное посягательство». Нельзя согласиться и с использованием понятия «нападение» для характеристики основания необходимой обороны. Нападение всегда содержит элемент насилия. Однако общественно опасное посягательство может осуществляться с использованием беспомощного состояния потерпевшего лица. Согласно буквальным толкованием закона основанием необходимой обороны посягательства, представляет общественную опасность и не обязательно является преступным. Преступность деяния означает наличие всех признаков состава преступления - совершение субъектом преступления, предусмотренного уголовным законом общественно опасного деяния. Согласно выводам автора при необходимой обороне посягательство должно быть направлено на государственные, общественные интересы, а также политические, трудовые и имущественные права граждан, личности, ее честь и достоинство, чтобы его можно было квалифицировать как общественно опасное. Основанием необходимой обороны может быть и такое общественно опасное посягательство, которое не образует нападения. Поскольку в законе речь идет о предотвращении или пресечении попытки лица совершить действие, которое представляет общественную опасность, очевидно, имеется в виду определенная 
активность личности. В законе не указано, что посягательство должно быть сопряжено с насилием, оно должно быть общественно опасным. Проанализирована научная дискуссия о возможности необходимой обороны против посягательства в форме бездействия. Среди всех обстоятельств, исключающих преступность деяния, только необходимая оборона - это реакция на общественно опасное посягательство, которое возможно и в активной форме, и в пассивной. По мнению автора, нет основания для права на необходимую оборону при общественно опасном бездействии.

Ключевые слова: необходимая оборона, нападение, основание необходимой обороны, общественно опасное посягательство, бездействие.

Andrusiak G. The Essence of Socially Dangerous Encroachment in the Context of the Necessity Defense. The article substantiates the correctness of determining the basis of necessary defense as a socially dangerous encroachment. In focus is the semantics of the concept of necessity, because the term is rather ambiguous. The basis of the necessary defense is the commission of a socially dangerous encroachment. We approve the using of such term by legislator, and not «attack» or «criminal encroachment». It is also impossible to agree with the using of the term «attack» to describe the basis of the necessary defense. An attack always contains an element of violence. However, a socially dangerous encroachment may be carried out using the helpless state of the victim. According to the literal interpretation of the law, the basis of necessary defense is encroachment, which is a public danger and is not necessarily criminal. The criminality of an act means the presence of all the elements of a crime - the commission by a subject of a crime of a socially dangerous act provided by criminal law. According to the author, in case of the necessary defense, the encroachment should threaten the state or public interests, political, labor, and property rights of citizens or individuals, their honor and dignity. Only in these contexts, it can be classified as socially dangerous. Other forms of encroachment, not only an attack, can be interpreted as socially dangerous and a reason for the necessary defense. Since the law involves the prevention or cessation of a person's attempt to commit an act that presents a public danger, it obviously implies a certain activity of the person. The law does not read that encroachment is always combined with violence - it must be just socially dangerous. The author highlights the scientific discussion on the admissibility of necessity defense against encroachment, which is not in action. Among all the circumstances that exclude the criminality of the act, only the necessity defense is a reaction to a socially dangerous encroachment, which is possible both in an active form and in a passive one. According to the author, there is no basis for the right to necessary defense in case of socially dangerous inaction.

Key words: necessary defense, attack, reason for necessity defense, socially dangerous encroachment, inaction. 